\title{
Endocrine control of nutrient partition in lactating ruminants
}

\author{
By I. C. HaRT, National Institute for Research in Dairying, Shinfield, Reading, \\ Berks RG2 gAT
}

The subjects of nutrient partition during lactation in ruminants and the hormonal control of the relevant aspects of metabolism, particularly in relation to blood hormone concentrations, have been extensively reviewed (Convey, 1974; Bassett, 1978; Bines \& Hart, 1978; Trenkle, 1978, 1981; Bauman \& Currie, 1980; Bell, 1980; Cowie et al. 1980; McDowell, 1983). The purpose of this paper is to describe the metabolic situation in lactating cows; to briefly emphasize the more important aspects of the hormonal control of nutrient partition and to describe two of our recent experiments on the manipulation of hormone secretion.

\section{Metabolic status of the high-yielding dairy cow}

The capacity of the cow to produce milk is determined by a combination of the growth and development of the mammary gland before and during pregnancy and the animal's ability to supply the substrates for milk synthesis once lactation is established. It is still not clear which of these factors is more important for maximum milk production. There is no doubt that, despite decades of intensive breeding, considerable variation remains in the ability of individual cows to produce what is currently regarded as a good milk yield in the UK $(6000-8000 \mathrm{~kg}$ milk in a $305 \mathrm{~d}$ lactation). Some of the reasons for this variation are obviously genetic in origin and this is easily demonstrated by comparing the changes in milk yield and body-weight that occur during lactation in beef and dairy breeds of cattle offered the same ration (Hart et al. 1975, 1978, 1979). The former produce low yields of milk, in accordance with the smaller mammary gland, and preferentially partition dietary energy to milk production and supplement this by mobilizing considerable amounts of body tissue. This is an important economic consideration because improved milk yield in early lactation is associated with a proportionately greater partitioning of nutrients towards milk at the expense of body reserves at mid-lactation (Broster, 1976).

Bauman \& Currie (1980) have used the data of others to examine the relationship between energy intake and requirements for lactation in high-yielding cows (average $9534 \mathrm{~kg}$ milk containing $332 \mathrm{~kg}$ fat in a $305 \mathrm{~d}$ lactation). As expected, they found that the peak in milk yield preceded maximum dietary intake by several weeks and that during the first one-third of lactation the cows were in negative energy balance and mobilizing body tissue. In fact the cows did not consume sufficient energy to meet their requirements until approximately $\mathrm{I} 6$ weeks of lactation when milk yield had fallen to less than $80 \%$ of peak production. They emphasized this situation by calculating that during the first month of lactation the 
energetic equivalent of $33 \%$ of the milk was produced from body reserves. Thus at peak lactation, and for several weeks after, the metabolism of the high-yielding dairy cow is orientated towards satisfying the considerable demands of its udder. During this period changes occur in most areas of intermediary metabolism and all of these changes are, to a greater or lesser extent, coordinated and integrated by the cow's endocrine system.

To consider this integration in terms of individual hormones is an over-simplification. Hormonal control is a function of several processes including the concentration of hormones in the blood and the number and affinity of hormone receptors; both of these processes may themselves be hormonally regulated. Furthermore, certain hormones can play both catabolic and anabolic roles (e.g. growth hormone, glucocorticoids and thyroid hormones) depending upon the metabolic status of the animal and the process considered. Fig. I is a diagramatic summary, derived from ruminant and non-ruminant data, of the hormones most likely to be concerned with three important aspects of supplying the mammary gland with nutrients, i.e. (I) mobilizing body fat and protein reserves, (2) increasing the rate of gluconeogenesis, particularly at the liver and (3) diverting the products of digestion and intermediary metabolism away from tissue deposition thus making them available for milk synthesis. From both a hormonal and metabolic standpoint these processes are interdependent; it is convenient, however, to consider points ( $\mathrm{I}$ ) and (2) under the following heading and point (3) separately.

\section{Hormonal control of nutrient supply}

Unlike the situation in non-ruminants, blood glucose is not a significant source of carbon for ruminant milk fat synthesis (Baldwin \& Plucinski, 1977). The fatty acids in cows' milk are primarily synthesized from plasma triglycerides, acetate

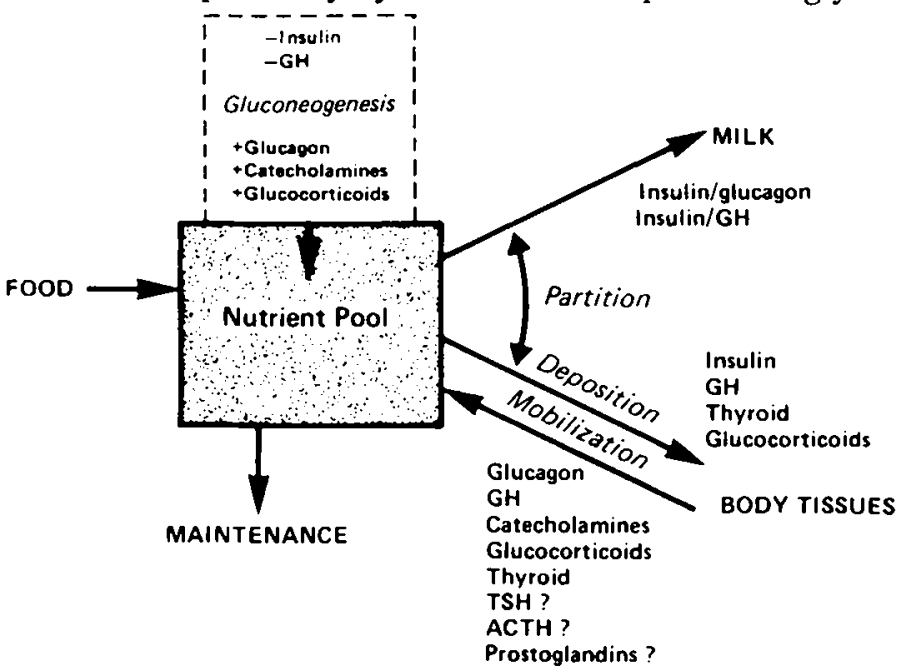

Fig. I. Hormones probably involved in the partition of nutrients between body tissue and the mammary gland. Derived from ruminant and non-ruminant data. GH, growth hormone; TSH, thyroid-stimulating hormone; ACTH, adrenocorticotrophic hormone. 
and $\beta$-hydroxybutyrate. Although each of these is derived from the diet, at peak lactation the availability of all three precursors, to some extent, depends on the products of lipolysis (Bell, 1980). It is essential, however, that the ruminant mammary gland receives a constant and adequate supply of glucose for milk lactose synthesis. Annison \& Linzell (1964) originally determined that the lactating goat utilized for milk production, between 60 and $85 \%$ of the total glucose used by the animal, and Elliot (1976) has calculated that a cow producing $40 \mathrm{~kg}$ of milk needs around $3045 \mathrm{~g}$ of glucose each day. This huge requirement is met partially by an increased intake of what is often a high starch diet. However, increased absorption of glucose from the hindgut is relatively small in comparison with the quantity of additional glucose, produced from the increased rate of hepatic gluconeogenesis which occurs at the onset of lactation (Bennink et al. 1972; Elliot, 1976).

It is well established that the primary gluconeogenic precursors in ruminants are propionate (intestinal absorption), amino acids (intestinal absorption, proteolysis), glycerol (lipolysis) and lactic acid (intestinal absorption, muscle metabolism); the first is quantitatively the most important during lactation. Although the liver may retain a degree of autonomy in glucose homoeostasis, results from studies in ruminants and non-ruminants suggest that insulin, glucagon, catecholamines and glucocorticoids are primarily responsible for regulating both the supply of gluconeogenic substrates and modulating the gluconeogenic pathway in the liver (Exton, 1979).

\section{Hormones stimulating gluconeogenesis and tissue mobilization}

There are two ways in which gluconeogenesis is promoted by glucagon and the catecholamines: both directly stimulate the process at the liver causing rapid inactivation of L-type pyruvate kinase. For glucagon, the effect is mediated by cAMP and cAMP-dependent protein kinase, whereas the catecholamines are thought to be released from nerve endings within the liver and operate via $\alpha$ - and $\beta$-adrenergic receptors. In addition, both enhance the supply of gluconeogenic and milk-fat precursors by mobilizing free fatty acids and glycerol from adipose tissue and the catecholamines stimulate lactate production from muscle.

The glucocorticoids exert a permissive influence on both the lipolytic action of the catecholamines and other hormones and on the gluconeogenic effect of the catecholamines and of glucagon at the liver. In addition, cortisol stimulates mobilization of amino acids from muscle. The thyroid hormones, thyroidstimulating hormone (TSH), adrenocorticotrophic hormone (ACTH) and the prostaglandins are all known to stimulate aspects of tissue mobilization, most commonly lipolysis, but the relative importance of these hormones in supplying gluconeogenic and milk-fat precursors has yet to be established.

\section{Hormones inhibiting gluconeogenesis and tissue mobilization}

Bassett ( 1978 ) has emphasized the importance of insulin in regulating ruminant metabolic homoeostasis. The hormone plays the predominant inhibitory role both 
in tissue mobilization and gluconeogenesis. By inhibiting the release of glucogenic and other amino acids from skeletal muscle and by antagonizing the stimulatory effects of glucagon and the catecholamines on lipolysis, insulin reduces both the supply of gluconeogenic substrates and possibly the availability of triglycerides and amino acids for milk fat and protein synthesis respectively. In addition to these peripheral effects, the hormone exerts a direct influence on the liver to inhibit the stimulation of gluconeogenesis by glucagon and the catecholamines.

Growth hormone (GH) promotes amino acid transport and protein synthesis and therefore would be expected to reduce the flow of amino acids to the liver and mammary gland. A long-term inhibitory effect of $\mathrm{GH}$ on hepatic amino acid metabolism is indicated by the increased amino acid transport, ureogenesis and gluconeogenesis observed in the liver of hypophysectomized rats (Tolman et al. 1973). Whilst there is no evidence to suggest that the rate of gluconeogenesis is reduced in cows treated with bovine $\mathrm{GH}$, recent results suggest that the hormone can reduce the concentration of protein in milk, particularly at mid-lactation (Bines et al. 1980; G. McDowell, I. C. Hart and J. A. Bines, unpublished results).

\section{Hormonal control of energy partition}

Insulin. Having established the mechanisms by which a satisfactory supply of metabolites are available for milk synthesis, the question of their partition between the mammary gland and body tissue is governed, to a considerable extent, by the influence of insulin relative to that of those hormones which chronically inhibit aspects of tissue deposition, most notably GH, glucagon and glucocorticoids. Although there may be differences in emphasis, to comply with the ruminant mode of digestion and intermediary metabolism (Bauman, 1976; Bassett, 1978), insulin exerts the same anabolic actions in ruminants as in non-ruminants, i.e. it stimulates the incorporation of glucose, amino acids and fatty acids into body tissues.

It has been known for some years that treatment of lactating cows with insulin causes an immediate reduction in milk yield which can be reversed by infusing glucose (Kronfeld et al. 1963). More recently, it has been suggested that the fall in milk-fat content resulting from a change to feeding high concentrate rations is caused by an increase in insulin secretion which stimulates lipoprotein lipase activity in adipose tissue and reduces the availability of fatty acids to the mammary gland (Rao et al. 1973; Jenny et al. 1974). Comparison of circulating insulin in high- and low-yielding cattle (Hart et al. 1975, 1978, 1979) revealed that during lactation the hormone was significantly higher in the plasma of low-yielding cows, which were in energy surplus and gaining body-weight, than in the high-yielders which were in energy deficit and losing weight during the early part of lactation. The difference in insulin disappeared when the animals ceased to lactate and throughout lactation a significant positive correlation was noted between changes in insulin and changes in body-weight. Furthermore, Lomax et al. (1979) have found that the insulin response to glucose infusion was greater in non-lactating than in lactating cows. 
The foregoing evidence strongly suggests that when high-yielding cows are in energy deficit insulin is suppressed, thus reducing the removal of metabolites by body tissue and increasing the rates of gluconeogenesis, lipolysis and proteolysis. This contention is supported by the results of our recent study in which high- and low-yielding cows were fed to similar changes in live weight. Under these same metabolic conditions the differences in insulin response were no longer apparent (Fig. 2). In this context it is interesting to note that glucose uptake and lactose production by the goat mammary gland are not impaired by low circulating levels of insulin (Hove, 1978). It is possible, therefore, that the ruminant mammary gland is at an advantage when competing for glucose with other body tissues which require higher levels of insulin for glucose uptake.

Insulin:glucagon. Bassett $(1975,1978)$ has already discussed the implications of Unger's (1971) proposals regarding the importance of the molar ratio of insulin:glucagon for the peripheral utilization of glucose in ruminants and it was generally assumed that the ratio needed to be low to maximize the availability of glucose for milk production. Recent measurements of pancreatic glucagon in plasma, taken throughout $24 \mathrm{~h}$ periods in high- and low-yielding cows during lactation, indicate that this may not be the case (I. C. Hart and J. A. Bines,
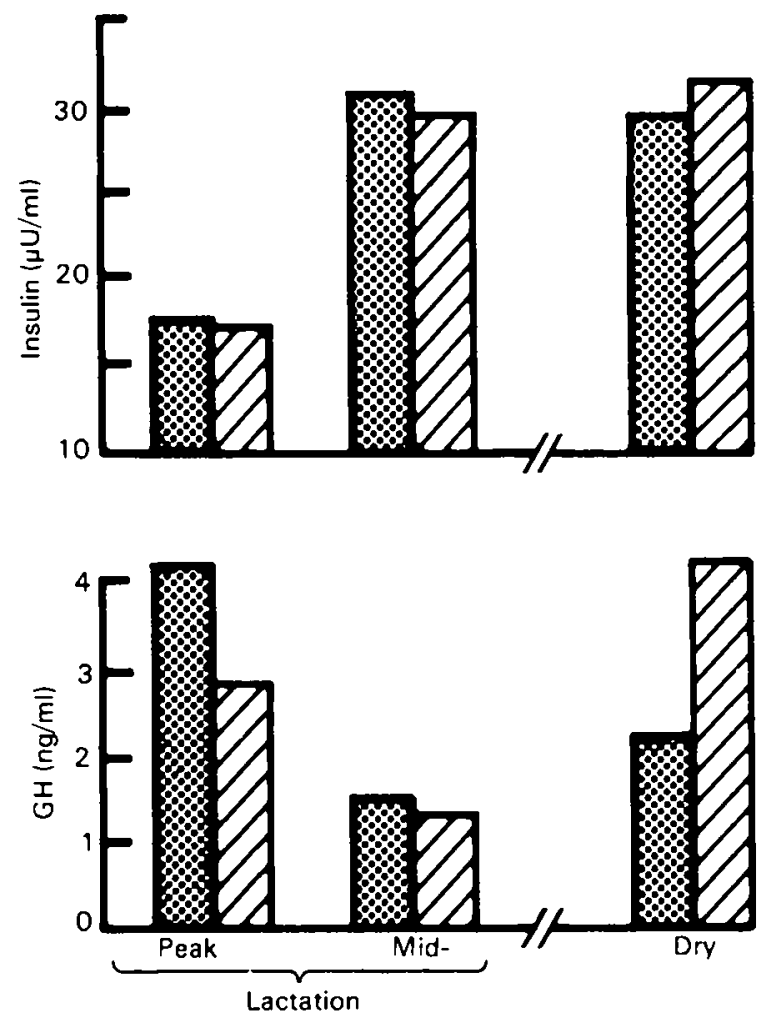

Fig. 2. Average concentrations of insulin and growth hormone (GH) measured throughout $24 \mathrm{~h}$ periods in high- $(\square)$ and low-yielding (B) cows fed to similar live weight change (J. A. Bines and I. C. Hart, unpublished results). 
unpublished results). Glucagon tended to be higher in the low-yielding group which had higher levels of insulin and were partitioning nutrients towards body tissue. Furthermore, there was an apparent increase in glucagon in both groups as milk yields fell from peak lactation towards drying off. It is possible that these results are misleading and that the role of the ratio of insulin:glucagon in nutrient partitioning would have been better characterized by more intensive study of the period after feeding (Bassett, I975). There is no doubt, however, that a systematic examination of glucagon in this context is desirable.

Growth hormone. It has been known for many years that GH is important for the maintenance of ruminant lactation. Injections of the hormone will increase milk yield and hormone replacement therapy in hypophysectomized lactating goats has shown that once lactation has been re-established the secretion of milk cannot continue in the absence of GH (see Cowie et al. 1980). The wide-ranging effects of the hormone on protein, carbohydrate, fat and mineral metabolisms have been tabulated by Machlin (1976) and there seems no reason at present to dispute Raben's (1973) general conclusion that the primary metabolic role of GH is to preserve body protein, particularly during periods of energy deficit, by inhibiting proteolysis and stimulating the incorporation of amino acids into muscle, whilst diverting glucose and fatty acids away from tissue deposition thus making them available as sources of energy. Although this hypothesis may have to be reassessed to take account of the current discussion regarding the molecular heterogeneity of $\mathrm{GH}$ and its biological activities (see below) it seems highly likely that the hormone plays a substantial role in partitioning nutrients away from deposition towards milk production. This view is supported by several facts: (I) plasma GH is higher in high- as compared with low-yielding cows and this difference is not evident when the cows are in similar metabolic states (Hart et al. 1975, I978; see Fig. 2), (2) changes in GH are positively correlated with changes in milk yield (Hart et al. 1980) and (3) treatment with the hormone appears to increase the efficiency with which cows convert food into milk (Machlin, 1973; Bines et al. 1980).

The mechanism by which $\mathrm{GH}$ increases milk yield in cows has yet to be defined. The most likely explanation, from a metabolic standpoint, is that the hormone increases the availability of milk precursors by stimulating lipolysis and partitioning glucose and acetate away from tissue deposition (Welt \& Wilhelmi, 1950; Young, 1953; Orth et al. 1960; Winegrad, 1962; Levine \& Luft, 1964; Luft \& Guillemin, 1974). The results obtained when high- and low-yielding cows were treated with GH whilst being given the same ration (Bines et al. 1980) are compatible with at least part of this theory. Although the percentage increase in milk yield was similar in both groups there was obviously a greater absolute increase in the high-yielders. A significant elevation in plasma glucose was only noted, however, in the low-yielding group. The possibility exists, therefore, that GH increased the availability of glucose for milk production to the same extent in both types of cow but it was only completely utilized by the high-yielders for their greater milk production.

Although treatment of sheep with $\mathrm{GH}$ has resulted in raised plasma glucose 


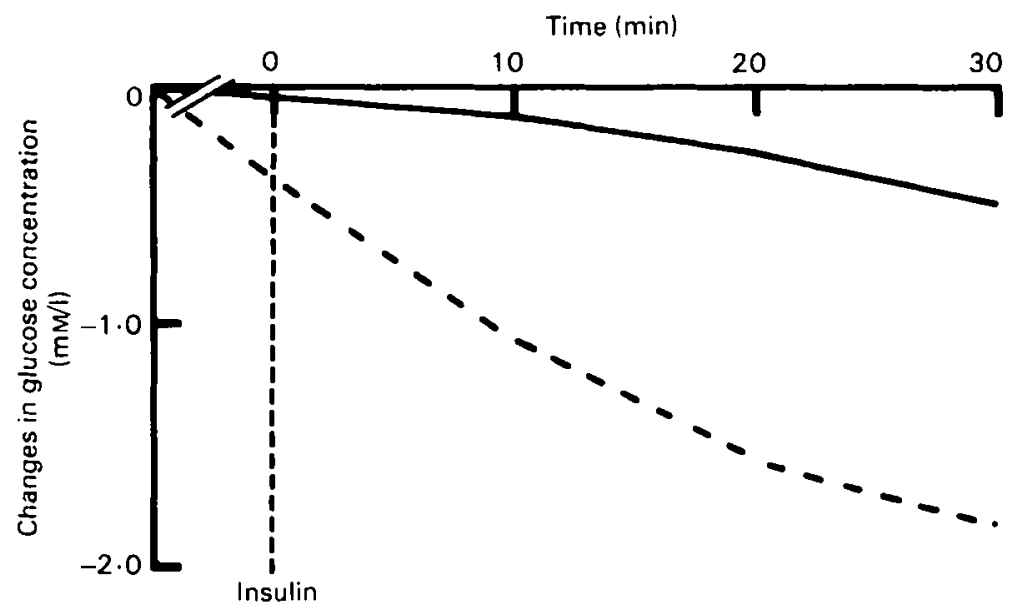

Fig. 3. Insulin tolerance test in three goats treated for $2 \mathrm{~d}$ with saline $(---)$ or bovine growth hormone (-—) (NIH-GH-B I $8 ; 0.3 \mathrm{mg} / \mathrm{kg}$ per d).

(Wallace \& Bassett, I966; Bassett \& Wallace, I966) there was no evidence, until recently, that bovine $\mathrm{GH}$ was diabetogenic in ruminants. We have recently shown that bovine GH inhibits the insulin-stimulated removal of glucose from the blood of goats (Fig. 3) and that this activity is related to the ability of the hormone to inhibit $3-0-\left[\mathrm{U}^{14}-\mathrm{C}\right]-$ methylglucose transport in rat epididymal fat tissue in vivo.

The lipolytic role of $\mathrm{GH}$ in ruminant lactation has been discussed recently elsewhere (Cowie et al. 1980).

Although there are compelling reasons to suspect that $\mathrm{GH}$ is important for energy partition, uncertainty remains as to whether simply providing the mammary gland with additional nutrients stimulates increased milk production. Linzell ( 1967 ) demonstrated a $62 \%$ increase in milk yield within $3 \mathrm{~h}$ of starting to infuse glucose into goats starved for $24 \mathrm{~h}$. The results for fed goats were less consistent and supplementation with acetate or amino acids had no additional effect. Likewise, post-ruminal infusion of glucose into lactating cows has yielded equivocal results. Clark (1975) reported an unpublished study in which abomasal infusion of $2 \mathrm{~kg}$ glucose/cow per d increased milk yield from 26.7 to $28.6 \mathrm{~kg} / \mathrm{d}$, whereas others (Tyrrell et al. 1972; Ørskov \& Grubb, 1977) have obtained negligible responses. It is possible that these inconsistencies were caused either by the animals' inability to absorb the supplementary glucose or variable insulin responses which would divert the glucose towards tissue deposition. Increasing the supply of fatty acids, either by intravenous and post-ruminal infusion or feeding protected lipids, markedly alters milk-fat composition, but once again the effect on milk yield is less consistent (Storry \& Rook, I965; Storry, r981). Whatever the explanation for these variable results there is some reason for proposing that GH might exert an effect in addition to increasing metabolite supply. 
Mammary blood flow has recently been measured in lactating goats treated with GH and related to changes in milk yield, milk protein and the mammary uptake of glucose and amino acids (Hart et al. 1980; Mepham et al. 1983). On some occasions, an increase in mammary blood flow was noted without an increase in milk yield. There is a possibility, therefore, that an increase in yield is preceded by an increase in mammary blood flow and that this is a contributory factor in increasing the supply of nutrients to the gland. Machlin (1973) suggested that $\mathrm{GH}$ might directly stimulate the synthetic capacity of the mammary gland based upon results in which the exogenous hormone enhanced milk yield in cows for several days after injections had ceased. He did not, however, consider the possibility that increased availability of milk precursors might itself cause an increase in milk synthesis and thereby potentiate milk production. Marinez et al. (1976) demonstrated that, when combined with dexamethasone and prolactin, $\mathrm{GH}$ stimulated the activity of acetyl CoA-synthetase in the goat mammary gland to a greater extent than when the other two hormones were given alone. More recently, we have fitted lactating goats with catheters in the mammary arteries (external pudendal artery) and infused one half of the udder with saline and the other half with doubling doses of bovine $\mathrm{GH}$ (bGH) (100-1600 $\mathrm{\mu g} / \mathrm{d}$ for $4 \mathrm{~d}$ periods). Although these experiments are still in progress, the preliminary results from three goats suggest that the hormone does not exert a direct galactopoietic influence on the mammary gland (G. McDowell and I. C. Hart, unpublished results).

Heterogeneity of bovine $G H$. It has been known for several years that human $\mathrm{GH}(\mathrm{hGH})$ is heterogeneous when subjected to several analytical and chromatographic procedures. These studies have shown that the diabetogenic and lipolytic activity of the hormone can be separated from the growth-promoting activity as individual proteins (Frigeri, 1980; Hart, I980; Lewis et al. 1980). It is not yet clear whether the separated components are fragments or modified forms of the hGH monomer or are contaminants of the original crude preparations. If the same were true for the bovine hormone it would present us with an opportunity to examine the effect of these separate metabolic activities on milk production and further our knowledge of important factors controlling energy partition in lactating cattle.

We have fractionated crude extracts of bovine anterior pituitaries and obtained four protein peaks (A-D), all of which contained bGH, detected by radioimmunoassay, and no prolactin. Analysis by high performance liquid chromatography and sodium dodecylsulphate-polyacrylamide gel electrophoresis, showed that fraction A was a heterogeneous collection of proteins, fractions $B$ and $C$ resolved into three components and, on most occasions, fraction $\mathrm{D}$ was a single protein of $\approx 22000$ daltons. When tested for growth-promoting activity (rat tibia test) fraction $A$ was inactive, fractions $B$ and $C$ were of intermediate activity and fraction $D$ had high growth-promoting activity. Assessment of diabetogenic activity (insulin tolerance test in goats; $3-\mathrm{O}-\left[\mathrm{U}^{14} \mathrm{C}\right]$-methyl glucose transport in rat epididymal fat) showed only fractions $B$ and $C$ to be diabetogenic. All of the fractions were lipolytic (glycerol release from rat epididymal fat in vitro). It is 
apparent, therefore, that the diabetogenic, lipolytic and growth-promoting activities of bGH are separable and we are continuing to extract and characterize these proteins in order to examine their metabolic activities and abilities to stimulate milk production in cows (I. C. Hart, P. M. E. Dardis, A. D. Simmonds and G. A. Payne, unpublished results).

Glucocorticoids. The role of the glucocorticoids in ruminant metabolism and lactation has recently been reviewed (Cowie et al. 1980; Baird, 1981; McDowell, 1983). Although the hormones clearly play a part in supplying nutrients for milk synthesis their role in the partition process is less clear.

\section{Recent work on the manipulation of hormone levels by physiological means}

The foregoing suggests that reducing the influence of insulin relative to that of GH would partition nutrients away from body tissue deposition towards milk production. Although the secretion of both hormones can be manipulated pharmacologically, such techniques can lead to residues in milk and tissue rendering the products unfit for human consumption. The production of bGH by bacteria as a result of recombinant DNA technology has recently become a practical and attractive possibility (Keshet et al. 1981), as the hormone stimulates milk production at physiological concentrations and is biologically inactive in humans; but it will be some time before recombinant bGH becomes commercially available.

At present one of the most accessible methods of manipulating insulin and $\mathrm{GH}$ secretion is by altering aspects of the animals' feeding and nutrition. It is well known that the concentrations of both hormones in blood are modified by changes in the time of feeding, the quantity of food consumed and the composition of the ration (Trenkle, 1978, 1981). During the last few years we have examined several of these factors in lactating cattle and these studies have provided data of basic interest. Two experiments have indicated areas which might be of practical importance.

Feeding frequency. It is well established that feeding rations containing high proportions of concentrates can change the partition of energy away from milk production towards body gain and in its extreme form this process can lead to the low milk fat syndrome. Recent experiments have suggested that this response might be reduced by more frequent feeding of concentrates but results have been inconsistent (Kaufman et al. 1975; van den Honing et al. 1976; Kirchgessner et al. 1980).

The possibility that insulin is implicated in this process has been discussed. Previous work, by others, had established the presence in ruminants of a post-prandial increase in plasma insulin which could last for several hours and we had determined that the magnitude of this response increased with both the quantity of food offered and the proportion of concentrates to hay (I. C. Hart and J. A. Bines, unpublished results). It seemed likely, therefore, that more frequent feeding of high concentrate diets might reduce the post-prandial peaks in insulin 
secretion and thereby remove a factor tending to partition nutrients towards body tissue.

This possibility was examined recently in a study with sixteen lactating cows (Sutton et al. 1983). Eight cows were given a ration containing $700 \mathrm{~g}$ concentrate $/ \mathrm{kg}$ ( $5.0 \mathrm{~kg}$ hay $+\mathrm{II} .5 \mathrm{~kg}$ concentrate) and $900 \mathrm{~g}$ concentrate $/ \mathrm{kg}$ ( $1.6 \mathrm{~kg}$ hay $+\mathrm{I} 4.0 \mathrm{~kg}$ concentrate). These rations provided similar amounts of digestible energy ( $180 \mathrm{MJ} / \mathrm{d}$ ) and nitrogen $(0.4 \mathrm{~kg} / \mathrm{d})$. Each ration was given to groups of four cows as either two (at 06.00 and 14.00 hours) or six (every $4 \mathrm{~h}$ ) equal meals each day. Hormone concentrations were measured in blood collected hourly over $24 \mathrm{~h}$ periods during early and late lactation.

The results of this study are summarized in Table 1 . Milk yields and contents and yields of protein and lactose were similar for all groups. There were, however, significant differences for content and yield of milk fat associated with both proportion of concentrate in the ration and frequency of feeding. Fat content and yield were lower for cows fed twice rather than six times daily irrespective of the proportion of concentrate in the ration. Further, both content and yield of milk fat were lower for cows given $900 \mathrm{~g}$ compared with cows given $700 \mathrm{~g}$ concentrate $/ \mathrm{kg}$.

Prolactin, GH and thyroxine did not change with feeding frequency but the average concentration of insulin throughout the $24 \mathrm{~h}$ period was almost halved in the group given $900 \mathrm{~g}$ concentrate/ $\mathrm{kg}$ six times daily when compared to the group fed twice daily (Table 1). This was due to the virtual elimination of the post-prandial insulin peaks in the group fed six times daily (Fig. 4). Although the results for the group given $900 \mathrm{~g}$ concentrate/ $\mathrm{kg}$ strengthens the case for the role of insulin in partitioning energy away from milk, the average concentration of insulin obtained throughout the $24 \mathrm{~h}$ period in the group given $700 \mathrm{~g}$ concentrate $/ \mathrm{kg}$ did not differ between those fed twice and six times daily and yet there was a significant difference in both the content and yield of milk fat (Table $I$ ). Examination of the hourly insulin profile for these animals (Fig. 4) shows that the group fed twice daily still exhibited marked post-prandial insulin peaks. It is possible, therefore, that the increases in insulin after feeding (when the rate of

Table I. Effect of feeding frequency and diet composition on milk yield, milk fat content and yield and the average concentrations of hormones in blood samples taken in early and mid-lactation

\begin{tabular}{|c|c|c|c|c|c|}
\hline Concentrates ( $\mathrm{g} / \mathrm{kg}$ diet) ... & & & & & \\
\hline Meals/d... & 2 & 6 & 2 & 6 & \\
\hline Milk yield $(\mathrm{kg} / \mathrm{d})$ & $19 \cdot 7$ & $20 \cdot 2$ & $23 \cdot 0$ & $21 \cdot 4$ & \\
\hline Milk fat content $(\mathrm{g} / \mathrm{kg})$ & $32 \cdot 6$ & $39 \cdot 2$ & $17 \cdot 9$ & $29 \cdot 7$ & $\mathrm{DF}^{\bullet}$ \\
\hline Milk fat yield $(\mathrm{kg} / \mathrm{d})$ & 0.64 & 0.79 & 0.42 & 0.62 & $\mathrm{DF}^{\bullet}$ \\
\hline Insulin $(\mu \mathrm{U} / \mathrm{ml})$ & 10.9 & 10.1 & 27.8 & 14.4 & $\mathrm{DF}^{\bullet}$ \\
\hline Prolactin (ng/ml) & 74 & $5 \cdot 1$ & $7 \cdot 5$ & $8 \cdot 5$ & \\
\hline Growth hormone $(\mathrm{ng} / \mathrm{ml})$ & $4 \cdot 4$ & $4 \cdot 2$ & $3 \cdot 4$ & $3 \cdot 1$ & \\
\hline Thyroxine (ng/ml) & 15.8 & 18.7 & $15 \cdot 3$ & 20.9 & \\
\hline
\end{tabular}

- Significant (at least $P<0.05$ ) diet composition (D) or feeding frequency $(F)$ effects. 
nutrient absorption is greatest) is more important for energy partition than the average concentration of insulin to which the animal is exposed throughout the day.

Feeding protected protein. Increasing the supply of amino acids to the intestine of dairy cows by abomasally infusing casein can increase both milk yield and the yield of milk protein (Oldham, I98I). Similar responses have been found when the protein content of the diet has been increased (Ørskov et al. 1981; Phipps et al. 1981). For some years it has been known that intravenous infusion of amino acids will raise plasma GH in cattle (Reynaert $e t$ al. 1972) and later work has established that abomasal infusion of casein will increase the hormone in ruminants (Oldham et al. 1978; Barry, 1980), although others have failed to find this (Gow et al. 1979; Peel et al. $198 \mathrm{r})$. It is possible, therefore, that part of the response in milk output to increasing the supply of amino acids to the intestine is mediated via increased secretion of $\mathrm{GH}$.

To investigate this possibility we (Oldham et al. 1982) measured the hormonal responses of seven lactating heifers ( $25^{-28}$ weeks post partum) given either casein, formaldehyde-treated casein (protein casein) or formaldehyde-treated soya (protected soya). Formaldehyde treatment reduces protein degradation in the rumen and increases the supply of amino acids to the abomasum.

Blood samples were taken hourly throughout the penultimate day of each treatment period and the hormone analyses revealed no significant difference in the average concentrations of insulin, prolactin and $T_{4}$ between the three treatment groups. When compared to the casein-fed group, the circulating concentration of GH was significantly increased by feeding protected casein or soya (Table 2). However, the extent of the increase was small when compared to the average concentration achieved by galactopoietic doses of the hormone in cattle (Bines et al. 1980). It was not surprising to find, therefore, that feeding protected protein did not result in increased milk yield nor altered milk composition. The fact that GH was increased in the absence of a change of milk production suggests that the

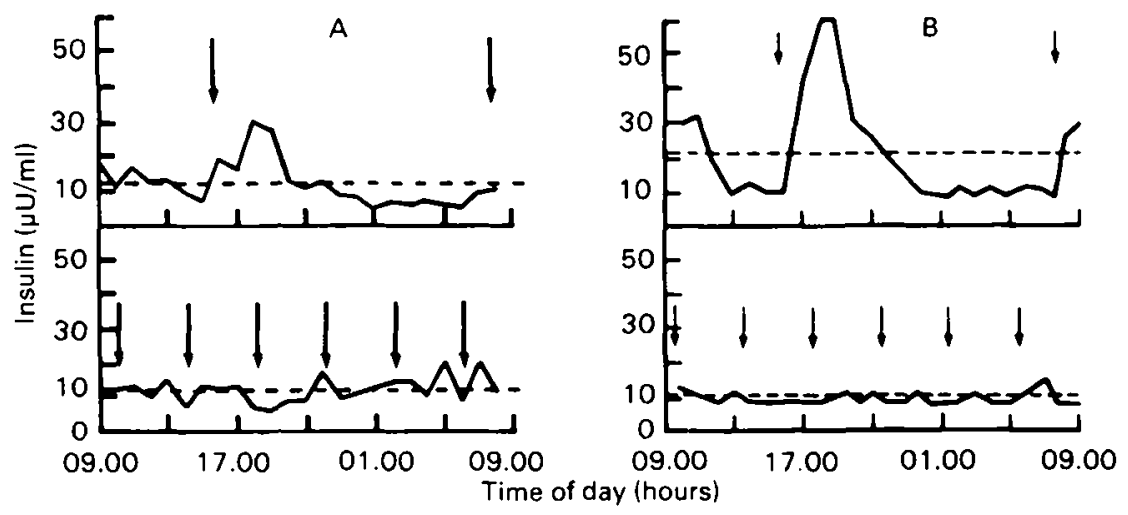

Fig. 4. Average circulating levels of insulin measured hourly in groups of four cows given rations containing (A) $700 \mathrm{~g}$ concentrate $/ \mathrm{kg}$ and (B) $900 \mathrm{~g}$ concentrate/ $\mathrm{kg}$ two and six times daily at approximately 22 weeks of lactation. (- - ), Mean concentration throughout the $24 \mathrm{~h}$ period; $($ ()), feeding. 
Table 2. Effect on milk yield and the concentrations of growth hormone, insulin, prolactin and thyroxine in blood of feeding rations containing casein, protected casein, or protected soya to heifers in mid-lactation

$\begin{array}{lcccc} & \text { Casein } & \begin{array}{c}\text { Protected } \\ \text { casein }\end{array} & \begin{array}{c}\text { Protected } \\ \text { soya }\end{array} & \begin{array}{c}\text { Standard error } \\ \text { of difference }\end{array} \\ \text { Milk yield }(\mathrm{kg} / \mathrm{d}) & 12.9 & 12.3 & 11.9 & 0.55 \\ \text { Growth hormone }(\mathrm{ng} / \mathrm{ml}) & 3.0 \mathrm{r}^{a} & 5.69^{b} & 5.39^{b} & 0.88 \mathrm{r} \\ \text { Insulin }(\mu \mathrm{U} / \mathrm{ml}) & 16.2 & 21.1 & 12.5 & 4.81 \\ \text { Prolactin }(\mathrm{ng} / \mathrm{ml}) & 15.8 & 14.0 & 13.8 & 3.25 \\ \text { Thyroxine }(\mathrm{ng} / \mathrm{ml}) & 48.4 & 40.3 & 44.9 & 3.88\end{array}$

a,b. Means which do not share a common superscript differ significantly $(P<0.05)$.

stimulatory effect of feeding protein on the hormone's secretion is independent of changes in the cow's energy status caused by increased milk synthesis.

Manipulating endocrine secretion by changing aspects of feeding and nutrition does not have the attractive simplicity of directly stimulating or inhibiting hormone production. Problems may arise when changes in the composition of the diet or the rate of nutrient delivery to the gut alter the cow's metabolic status such that the hormonal benefit is confounded. These two experiments indicate that there is scope for the nutritional manipulation of insulin and $\mathrm{GH}$ secretion and suggest that when rations are formulated for lactating cows some attention should be paid to the hormonal response they may elicit.

\section{REFERENCES}

Annison, E. F. \& Linzell, J. L. (1 964). F. Physiol. 175, 372.

Baird, G. D. (1981). Fedn Proc. Fedn Am. Socs exp. Biol. 40, 2530.

Baldwin, R. L. \& Plucinski, T. (1977). In Reproduction in Domestic Animals, p. 369 [H. H. Cole and P. T. Cupps, editors]. New York: Academic Press.

Barry, T. N. (1980). N.Z. Yl agric. Res. 23, 427.

Bassett, J. M. (1975). In Digestion and Metabolism in the Ruminant, p. $3^{8} 3$ [I. W. McDonald and A. C. I. Warner, editors]. Armidale, Australia: University of New England Publishing Unit.

Bassett, J. M. (1978). Proc. Nutr. Soc. 37, 273.

Bassett, J. M. \& Wallace, A. L. C. (r 966). Metabolism 15, 933.

Bauman, D. E. (1976). Fedn Proc. Fedn Am. Socs exp. Biol. 35, 2308.

Bauman, D. E. \& Currie, W. B. (1980). F. Dairy Sci. 73, 1514 .

Bell, A. W. (1980). Prog. Lipid Res. 18, 117.

Bennink, M. R., Mellenberger, R. W., Frobish, R. A. \& Bauman, D. E. (1972). J. Dairy Sci. 55, 712.

Bines, J. A. \& Hart, I. C. (1978). Proc. Nutr. Soc. 37, 28 I.

Bines, J. A., Hart, I. C. \& Morant, S. V. (I980). Br. F. Nutr. 43, I 79.

Broster, W. H. (1976). In Principles of Cattle Production, p. 27 I [H. Swan and W. H. Broster, editors]. London: Butterworths.

Clark, J. H. (1975). J. Dairy Sci. 58, i 178.

Convey, E. M. (1974). F. Dairy Sci. 57, 905.

Cowie, A. T., Forsyth, I. A. \& Hart, I. C. (1980). Hormonal Control of Lactation. Berlin: Springer-Verlag. 
Elliot, J. M. (1976). In Proceedings of the Cornell Nutrition Conference for Feed Manufacturers. A report of research of the Cornell University Agricultural Experimental Station, p. 59.

Exton, J. H. (1979). In Hormones and Energy Metabolism, p. 125 [D. H. Klachko, R. R. Anderson and M. Heimberg, editors]. New York: Plenum Press.

Frigeri, L. G. (1980). Endocrinology 107, 738 .

Gow, C. B., Ranawana, S. S. E., Kellaway, R. C. \& McDowell, G. H. (1979). Br. Y. Nutr. 41, 371.

Hart, I. C. (1980). In Hormones and Metabolism in Ruminants, p. 47 [H. M. Forbes and M. A. Lomax, editors]. London: Agricultural Research Council.

Hart, I. C., Bines, J. A., Balch, C. C. \& Cowie, A. T. (1975). Life Sciences 16, 285.

Hart, I. C., Bines, J. A. \& Morant, S. V. (1979). f. Dairy Sci. 62, 270.

Hart, I. C., Bines, J. A., Morant, S. V. \& Ridley, J. L. (1978). F. Endocr. 77, 333.

Hart, I. C., Lawrence, S. E. \& Mepham, T. B. (1980). F. Physiol. 308, 46 P.

Hove, K. (1978). Acta Physiol. Scand. 103, 173.

Jenny, P. F., Polan, C. E. \& Thye, F. W. (1974). Y. Nutr. 104, 279.

Kaufman, W., Rohr, K., Drenicke, R. \& Hagemeister, H. (1975). Sonderh. Ber. Landw. I9r, 269.

Keshet, E., Rosner, A., Bernstein, Y., Gorecki, M. \& Aviv, H. (1981). Nucleic acids Res. 9, 19.

Kirchgessner, M., Muller, H. L. \& Sax, J. (I980). Z. Tierphysiol. Tierernahr. Futtermittelk. 44, 279.

Kronfeld, D. S., Mayer, G. P., Robertson, J. M. \& Raggi, F. (1963). J. Dairy Sci. 46, 559.

Levine, R. \& Luft, R. (1964). Diabetes $13,651$.

Lewis, U. J., Singh, R. N. P., Tutwiler, G. F., Sigel, M. B., Vanderlaan, E. F. \& Vanderlann, W. P. (1980). Recent Prog. Horm. Res. 36, 477.

Linzell, J. L. (1967). F. Physiol. 190, 347.

Lomax, M. A., Baird, G. D., Mallison, C. B. \& Symonds, H. W. (1979). Biochem. F. 180, 281.

Luft, R. \& Guillemin, R. (1 974). Diabetes 23, 783 .

McDowell, G. (1983). Proc. Nutr. Soc. 42, 149.

Machlin, L. J. (1973). F. Dairy Sci. 56, 575.

Machlin, L. J. (1976). In IAEA/FAO Symposium on Nuclear Techniques in Animal Production and Health, p. 43 .

Marinez, D. I., Ricks, C. A. \& Cock, R. M. (1976). F. agric. Fd Chem. 24, 927.

Mepham, T. B., Lawrence, S. E. \& Hart, I. C. (1983). Horm. Met. Res. (In the Press.)

Oldham, J. D. (1981). In Recent Advances in Animal Nutrition--1980, p. 33 [W. Haresign, editor]. London: Butterworths.

Oldham, J. D., Hart, I. C. \& Bines, J. A. (1978). Br. F. Nutr. 37, 9A.

Oldham, J. D., Hart, I. C. \& Bines, J. A. (1982). Br. F. Nutr. 48, 543.

Orskov, E. R. \& Grubb, D. A. (1977). Proc. Nutr. Soc. 36, 56A.

Ørskov, E. R., Reid, G. W. \& McDonald, I. (1981). Br. F. Nutr. 45, 547.

Orth, R. D., Odell, W. D. \& Williams, R. H. (1960). Am. F. Physiol. 198, 640.

Peel, C. J., Fronk, T. J., Bauman, D. E. \& Gorewit, R. C. (1981). F. Dairy Sci. 64 (Suppl. 1), I 24.

Phipps, R. H., Weller, R. F., Smith, T. \& Fulford, R. J. (198 I). f. agric. Sci., Camb. 96, 283.

Raben, M. S. (1973). In Methods in Investigative and Diagnostic Endocrinology, p. 26I [S. A. Benson and R. I. Yalow, editors]. London: North Holland.

Rao, D. R., Hawkins, G. E. \& Smith, R. C. (1973). F. Dairy Sci. 56, I 4 I 5.

Reynaert, R., De Paepe, M. \& Peeters, G. (1972). Archs int. Pharmacodyn. Thér. 197, 405.

Storry, J. E. (1981). In Recent Advances in Animal Nutrition-1981, p. 3 [W. Haresign, editor]. London: Butterworths.

Storry, J. E. \& Rook, J. A. F. (1965). Biochem. F. $97,879$.

Sutton, J. D., Hart, I. C. \& Broster, W. H. (1983). Proceedings of the 9 th EAPP Energy Symposium. (In the Press.)

Tolman, E. I., Schworer, C. M. \& Jefferson, L. S. (r973). f. biol. Chem. 248, 4552.

Trenkle, A. (1978). F. Dairy Sci. 61, 28 r.

Trenkle, A. (I $98 \mathrm{I}$ ). Fedn Proc. Fedn Am. Socs exp. Biol. 40, 2536.

Tyrrell, H. F., Bolt, D. J., Moe, P. W. \& Swan, H. (1972). F. Anim. Sci. 35, 277.

Unger, R. H. (1971). Diabetes 20, 834 . 
van den Honing, Y., Bangma, G. A., Homan, G. W., Terluin, R., Thielen, B. \& Vog, J. E. (1976). In Energy Metabolism of Farm Animals, p. 77 [M. Vermorel, editor]. ClermontFerand: G. de Bussac.

Wallace, A. L. C. \& Bassett, J. H. (1966). Metabolism 15, 95.

Welt, I. D. \& Wilhelmi, A. E. (1950). Yale f. Biol. Med. 23, 99.

Winegrad, A. I. (1962). Vitams Horm. 20, 142.

Young, F. G. (1953). Recent Prog. Horm. Res. 8, $47 \mathrm{I}$. 